\title{
TERRORISM: INDIAN AND TURKISH EXPERIENCES
}

TÜRKKAYA ATAÖV

\section{Definitions:}

Modern democracy, which may be identified with popular sovereignty, majority rulc, constitutional liberties, participation in decision-making at all levels, egalitarianism, protection of minorities and much else, is a complicated package. No matter how composite it may look, however, democracy is incompatible with terrorism. ${ }^{1}$

Fascist parties excluded, most political groupings and governments have scldom failed to claim a democratic legitimacy. Democracy, which seems to promise a form of government based on the harmony between the rulers and the ruled, is irresistible, at least as a slogan. It is conceivable, however, only when sectional as well as public interests are acknowledged and organized for political action. Another assumption is that no state is seriously democratic unless opposition is permitted to organize and participate in the contest for power.

In some countries, opposition rests on tribes or regions, which may not accept a common good in the overall state. In societies where opposition forces are of this type, democratic institutions lead to clashes more than bringing harmony. In such instances, some kind of unifying principles in the form of an ideology, "guided democracy" and "army above politics" may

\footnotetext{
* Submitted to the International 'Conversazione' on Democracy and Terrorism, held in New Delhi, India, under the auspices of the International Institute for Non-Aligned Studies, July 25-26, 1996.

${ }^{1}$ Paul Wilkinson, Terrorism and the Liberal State, London, Macmillan, 1979; Terrorism versus Liberal Democracy; the Problem of Response, London, Institute for the Study of Conflict, 1976.
} 
emerge. Although even such governments are not necessarily without virtue, democracy assumed, during its formative centuries, the existence of rational human beings, a premise questioned in our times. Some analysts believe that the democratic process has its own irrationalities.

Likewise, it is difficult to use the term terrorism accurately within a legal context. "The man in the street", nevertheless, has a fairly well concept in his mind. One may say that it is a violent conduct directed against a person, a group of persons or the representatives of an authority, planned to intimidate or coerce the latter to meet the demands underlying the terrorist act. Only "hostile" terrorists cannot be labelled as such, and "friendly" ones overlooked. Although an act of terrorism may be committed for several purposes and may have long-term objectives, it may also have an immediate and a limited target. Whatever the goals are, "wars" are being waged by tiny platoons bearing strange devices. It is the isolation of a small group of people, who in most cases constitute much less than one percent of a movement they assert to represent, that pushes them to violence. In the meantime, by reducing politics to criminal action, the terrorists of our day disorganize the forces of change. Like the alchemists of old ages, they expect miracles from bombs and assassinations.

Actually an old form of violent behaviour, terrorism is, not only becoming an increasingly important element of world politics, but also expanding by virtue of its brutality, number of victims, geographical range and media effects. Arms smuggling, the marketing of narcotics, and the possibility of possession of nuclear arms make terrorism the scourge of our times.

One of the dominant features of recent terrorism has been the proliferation of groups motivated by religion, giving that kind of violence a "divine imperative". ${ }^{2}$ Contrary to the bias of some Western circles, it is not only Islam that puts forward religious terrorists. In addition to "holy terror" in parts of Kashmir, legitimization of violence is also discernible among some radical Sikhs in India, white supremacist American Christians, and Jewish messianic movements in Isracl. Strong sectarian elements may also be observed in Armenian, Irish, Palestinian and Tamil terrorist groups. Consequently, "Hamas" asserts that Israel will exist until Islam will obliterate it, Jewish fanatics plot the destruction of the Dome of the Rock, a Sikh group seeks to "cleanse" Punjab of foreign influences, and white supremacists lay plans to engage in indiscriminate, mass killings.

\footnotetext{
${ }^{2}$ Bruce Hoffman, " 'Holy Terror': The Implications of Terrorism Motivated by a Religious Imperative," Studies in Conflict and Terrorism, 18 (1995), pp. 271-284.
} 
The brand of terrorism which pretends to be a vehicle of "emancipatory" endeavours is not connected with the right of peoples to necessary self-defence. Instead, it is a dangerous form of abuse of the anticolonial and liberatory struggle, or it is an indication of a separate aim, with interests of its own. The so-called "anti-colonial terrorism" cannot be on a level with the goals of peoples struggling for national liberation. Such a movement does not endorse terrorist acts claiming human lives among innocent civilian populations either in the area of conflict or anywhere else.

In addition to ethnonationalism and religious fundamentalism, there are several potential sources of conflict. Many developing nations keep on acquiring significant quantities of advanced weapons. Some states situated in unstable regions are on their way to becoming nuclear powers. The possible relationship between proliferation and ethnicity or religion is indeed disturbing. Two security analysts warn: "Imagine the danger of an Islamic Pakistan and a Hindu India confronting one another with nuclear weapons over religious differences." 3

After this quoted remark one should immediately differentiate between two issues. In one respect, nuclear non-proliferation reflects a key political division largely along North-South lines. ${ }^{4}$ The United States defines it as preventing nuclear have-nots from becoming nuclear haves. But the nonnuclear countries remind one that the Non-Proliferation Treaty (1970) also mandates the existing nuclear powers to thoroughly destroy their nuclear weapons. The five nuclear countries, who are also permanent members of the U.N. Security Council, have not moved in that direction, but accumulated nuclear arms in their hands, instead. The countries of the South have the right to oppose this monopoly. But the quest of equity in international politics runs the risk of bringing some competing powers to a clash with nuclear arms.

The threat to use nuclear arms is the most alarming terrorist behaviour surpassing in consequences all other terrorist acts. The latter, however, are becoming more and more adept at using the media to their advantage. While many people insist that freedom of the press is essential in a democracy, some others believe that there is an urgent need for journalists to be curtailed when reporting on terrorism. ${ }^{5}$ While earlier experts in

\footnotetext{
${ }^{3}$ Richard H. Shultz, Jr. and J. Marlow Schmauder, "Emerging Regional Conflicts and U.S. Interests: Challenges and Responses in the 1990s," Studies in Conflict and Terrorism, 17 (1994), p. 9.

${ }^{4}$ Phyllis Bennis, Calling the Shots: How Washington Dominates Today's U.N., New York, Interlink Publishing Group, 1996, pp. 198208.

${ }^{5}$ Shane Kinston, "Terrorism, the Media and the Northern Ireland Conflict," Studies in Conflict and Terrorism, 18 (1995), pp. 203-231.
} 
political communication underlined that terrorists manipulated the media, ${ }^{6}$ more recent ones ${ }^{7}$ challenge the previous approaches that assert that the media lens magnifies violence and inflames popular opinion. Some of them note excessive media emphasis on anti-Western Third World terror. ${ }^{8}$

\section{Global Rise in Violence:}

Although this paper endeavours to offer some observations on terrorism in two Asian countries, it may be useful to remind that analogous situations also surface in Western societies, and fascistic impulse is likewise noticable in a number of developing countries.

Only fringe phenomena until recently, extreme political movements in Europe became significant, not only on account of violent attacks on minorities and immigrants, but also the power of racist political parties has increased, influencing some mainstream parties to compete for the right-wing vote. ${ }^{9}$ Rising unemployment, coupled with waves of refugces from the former Communist bloc, led large portions of the European clectorate to search for scapegoats. While foreigners and minorities were maltreated in many parts of Western Europe, the collapse of Communism unleashed ethnocentric feelings initially in parts of Eastern Europe and then in the whole continent.

Consequently, the future of Europe is unclear. The red light of warning is already on. Violent activities and growing electoral support for racist, anti-Semitic and xenophobic reactions may be pale forerunners of more to come.

France's Front National, founded in 1972 and led by Jan-Marie Lc Pen, is the largest far-right party in Europe, electorally supported on an antiimmigration platform. In addition to racially motivated violence from arson attacks against the homes of foreigners to desecrations of Jewish sites, rightwing parties such as the Republikaner Partei in Germany, the Movimento Sociale Italiano and Lega Nord in Italy, the British National Party, the

\footnotetext{
${ }^{6}$ Richard Clutterbuck, The Media and Political Violence, London, Macmillan, 1983; Philip Schlesinger, Graham Murdock and Philip Elliott, Televising Terrorism: Political Violence in Popular Culture, London, Comedia, 1983.

${ }^{7}$ Steven Livingston, The Terrorism Spectacle, Boulder, Colorado, Westview, 1994.

${ }^{8}$ Gabriel Weimann and Conrad Winn, The Theater of Terror: Mass Media and International Terrorism, Longman, 1994.

${ }^{9}$ Türkkaya Ataöv, "Rising Racism in Europe," Turkish Daily News, 21 January 1995.
} 
Freiheits-Partei in Austria and the Vlaams Blok in Belgium have increased their followings.

Racism and violence pose as serious questions in Germany as in France. The Berlin Wall fell, but "the psychological wall" (Die psychologische Mauer) persists. Now, it is rather perilous to be a foreigner (Als sländer) in Germany. ${ }^{10}$ Just like Hitler's National Socialists detested the Weimar Republic, contemporary neo-Nazis view German democracy with open contempt. ${ }^{11}$ Considering democracy as a degenerate political system inconsistent with Germany's historical tradition, the neo-Nazis aim to establish a totalitarian order. As part of this strategy, foreigners, guestworkers and Jews have been selected as specific targets of violence. It was on account of their pressure that Germany passed restrictive legislation preventing some refugees to seek political asylum. In addition to the Republikaner party, which won few parliament seats, and other right-wing partics, whose membership increased after Germany's unification, international terrorist groups such as the Kurdistan Workers' Party (Partia Karkaren Kurdistan, PKK), Indian Sikhs, Liberation Tigers of Tamil Eelam (LITE), the Lebanese Hizbollah and Serbian and Croatian groups operate on German soil.

Europe presently experiences a resurgence of anti-Jewish violence with strong racist colours. ${ }^{12}$ Old prejudices are in the foreground, even in places where there are no Jews. Even traditional forms such as Christian Judeophobia are on the rise. The future of the Jews in Europe is closely linked with the future of other minorities and the chances for a more toterant society.

With the demise of the bipolar structure of international relations, we are witnessing the outbreak of old conflicts and animosities among nations and peoples of the Balkans and East Central Europe. ${ }^{13}$ The way in which the international community dealt with the aggression, occupation, terror, genocide and ethnic cleansing in the former Yugoslavia will have a profound impact on the attitude towards Western Europe's own difficulties. It may also have repercussions on Russia, if the latter attempts to unify all Russians

${ }^{10}$ Adam M. Weisherger, "German Reunification and the Jewish Question," Mind and Human Interaction, 6/1 (February 1995), pp. 8-14.

11 James H. Anderson, "The Neo-Nazi Menace in Germany," Studies in Conflict and Terrorism, 18 (1995), pp. 39-46.

${ }^{12}$ Türkkaya Ataöv, "Anti-Semitism in Europe," Turkish Daily News, 24 January 1995.

${ }^{13}$ Vesna Pesic, "The Cruel Face of Nationalism," Journal of Democracy, $4 / 4$ (October 1993), pp. 101-103; Jenusz Bugajski, "The Fate of Minorities in Eastern Europe," ibid., pp. 85-99. 
according to some analysts, the central administration was becoming authoritative.

The growth of terrorism and the decline of the authority of the secular Indian state were interrelated. The weakening of the central administration fed the identities based on caste, religion or language. It was under these circumstances that Hindu ethnonationalism, against which India's founding fathers had warned, rose to new heights. Although the Muslims were divided internally, they all shared the opinion that they were underrepresented especially in the public sector. The destruction of the Babri Masjid, in the presence of the security forces, only served to add to the Muslim displeasure. The failure of the central government, not only encouraged Hindu fundamentalism, but also increased the militancy of the Muslims.

In the opinion of some analysts, ${ }^{19}$ religion covering the dispute around the Babri Masjid in Ayodhya (U.P.), believed by Hindus to be the birthplace of god Rame (Ram Janmasthan) was a cloak for a different kind of drama. On several occasions $(1853,1934,1949)$, men of Hindu sects occupied and partially destroyed the mosque. While the original dispute was a local one, the site became a symbol for a more abstract conflict in the late 1980s. For the Vishwa Hindu Parishad (VHP, World Hindu Organization), it turned into a symbol for its drive to wipe Islam off the face of "Hindu India". Aggressive Hindu organizations or their descendants like the Rastriya Swayamsewas Sangh (RSS) aimed at reestablishing a link between presentday India and its pre-Islamic past.

When the Bharatiya Janata Party (BJP), in searching ways and mcans to increase its support, tried to bring together, not only the backward castes and tribes, but also the Muslims on the same platform, some quarters interpreted this attempt as dividing the society on the basis of class, not caste. Later, Rajiv Gandhi's massive program of economic reforms weakened the alliance of the intermediate bourgeoisie with the Congress, and urged it to look for other political alternatives. It was at this critical period that the VHP tried to rouse dormant anti-Muslim and Hindu chauvinism. Some sections of the middle class broke away from the secular democratic parties, especially after V.P. Singh's National Front government announced that it was reserving 27 percent of the jobs in the central government and parts of the public sector for the backward classes.

As the class issue gained the upper hand, Hindu chauvinism more and more stratched out. The cultural driving force was hatred of the Muslim past, as evident in the plan to destroy the Babri Masjid and the threat to repeat it in

${ }^{19}$ Prem Shanker Jha, "The Fascist Impulse in Developing Countrics: Two Casc Studies," Studies in Conflict and Terrorism, 17 (1994), pp. $251 \mathrm{f}$. 
thousands of other places. Other Indians knew, however, that the 100 million Muslims were also citizens. Their place was India, not "Pakistan or Kabristan" (graveyard). The Muslim period of India was an inseparable part of the country's rich heritage. Not only Babur, the Turco-Moghul sultan from Central Asia who conquered North India, bringing relief to the indigenous people there from the oppressive Afghan dynasty, was a tolerant philosopherking of his time, but also the forces that destroyed the Babri Masjid and caused the murder of thousand were ignorant of the tolerant teachings of the Vedas and the Upanishads.

It is understandable, although not approvable, that Hindu and Muslim militancy would push each other to extremes and expand reciprocally. Similarly, some Sikhs resorted to violent activities with a demand for "Khalistan". The sequence of events from the assault on the Golden Temple to the massacre of more than $30(0)$ Sikhs apparently alinated sections of this minority from the central authority. While a group of militant Nagas also secks independence, the condition for Tamil identity changed from secession to autonomy. The Liberation Tigers of Tamil Eelam, a guerilla/terrorist group avowedly acting on behalf of the minority Tamil community fighting for a homeland in Sri Lanka, fought the Indian army, sent to disarm them, and, after the Indian pullout (199()), carried out the assassination of former Indian Prime Minister Rajiv Gandhi. ${ }^{20}$ The Indian authorities unravelled thereafter a network of supporters and depots in Tamil Nadu.

\section{Turkey:}

The Republic of Turkey is a secular democracy. Although it occasionally experiences difficultics with the working of the system, it is the only country with a predominantly Muslim population where democracy has florished within a sccular state. 21 "In Turkey democracy was neither bequeathed by imperial rulers, nor imposed by victorious enemics. It was the frec choice of the Turks themselves." 22

Thousands of years of Anatolian civilization created a culturally rich Turkish society. The values that unite the people of that country, like the citizens of India, outweigh those which separate them. Turkish history is full of outstanding instances of religious and ethnic tolerance such as the welcome the Turks gave to the Sephardic Jews flecing the Spanish

${ }^{20}$ Manoj Joshi, "On the Razor's Edge: The Liberation Tigers of Tamil Eelam," Studies in Conflict and Terrorism, 19/42 (1996), pp. 19-42.

${ }^{21}$ Ergun ()/budun, ed., Perspectives on Democracy in Turkey, Ankara, Turkish Political Science Association, 1988; C.H. Dodd, The Crisis of Turkish Democracy, 2nd ed., London, the Eothen Press, 1990.

${ }^{22}$ Bemard Lewis, "Rethinking the Middle East," Foreign Affairs, $71 / 4$ (Fall 1992). pp. 99 120. 
Inquisition in 1492 and to those escaping the Holocaust in the $1930 \mathrm{~s}$ and the 1940s.

Terrorism has also appeared in the contemporary Turkish scene in many different guises. ${ }^{23}$ It has brought suffering and death to innocent pcople through the hands of the extreme rightists, extreme leftists, foreignsponsored groups and a cluster that pretends to talk for the whole of an ethnic minority, the Kurds. The ultra groups in the right and in the left were guided by a thesis of an aggressive negation of reality. The armed conflict between their partisans for years claimed youthful lives, noted intellectuals and innocent by-standers. The social basis of ultra-right and ultra-left terrorism was made up of the representatives of the petty bourgoisic, of part of the student body and the lumpenproletariat. They both lived on extreme dissatisfaction, whipped up a climate of tension, and used their ideology as a means to make part of the younger generation take the path of violence. Their gangs obtained money through robberies, drug smuggling or from foreign sponsors. The terrorists assassinated professors, journalists, party leaders, trade unionists and administrators. Turkey has also been a target, at random, for foreign sponsored groups which have resorted to terrorist methods. An example is the massacre at an Istanbul synagogue of Jews offering prayers. Beginning with 1975, a sudden cruption of Armenian terror has been directed indiscriminately at Turkish diplomats and almost anyone else nearby. Not only Turkish missions, but also other agencies doing business with Turkey or even foreign governments were attacked in order to coerce them to be lenient on Armenians for the murder of Turks or for other crimes.

The separatist terrorism of a Kurdish organization, the PKK, is Turkey's priority problem. An expert defines the PKK as "the most violent gucrilla organization in the whole of the Middle East region." 24 It is often evaluated in the West as representing the Kurdish people in Turkey and Kurdish nationalism. However, the PKK's membership and the attitude of the majority of the Kurds as reflected in election returns indicate that this terrorist organization is far removed from representing the Kurds of Turkey. Many of its arguments are historically wrong, or greatly exaggerated. The Turkish governments, which progressively realized the seriousness of the situation, adopted different methods to confront the challenge. These methods include

${ }^{23}$ Türkkaya Ataöv, "Turkish Perceptions of Terrorism," The 1986 Annual on Terrorism, Dordrecht, the Netherlands, Martinus Mijhoff Publishers, 1987, pp. 101-108.

${ }^{24}$ A detailed study of the PKK organization: Ismet G. Imset, The PKK: Report on Separatist Violence in Turkey, Ankara, Turkish Daily News, 1992, p. 1. 
enormous state investments in southeastern Anatolia to ease the local people's economic problems.

The PKK was formed (1978) to realize a Communist revolution through guerilla warfare and an independent Kurdistan state. Some authors argue that international legal principles do not allow sovereignty for the Kurds. ${ }^{25}$ This view is not, of course, unchallenged. ${ }^{26}$ But only a very small percentage of the Kurds are militants, and very few of them entertain the thought of secession. A crushing majority, dispersed all over Turkey, are law-abiding citizens and sincerely oppose breaking away from Turkey. The PKK has no copyright over the fate of the Kurdish people. An American writer, very much in favour of Kurdish causes, admits, nevertheless, that the Kurdish "sense of ethnic unity is still poorly developed." 27

Although some militant Kurds assert, especially in foreign circles, that the Turks of the Ottoman as well as the Republican periods have never chosen to designate the ethnic Kurds as such and that this lack of recognition is a denial of their identity and therefore, a sure sign of discrimination, a better judgement should indicate just the contrary, namely, that the basic fact of the Ottoman millet (religious community) system of autonomous selfgovernment under their own leaders considered that a further division by ethnic lines was itself discriminatory. While the Armenians, the Jews, the Christian Orthodox, the Catholics and the Protestants were grouped separately under their religious leaders, all the Muslim citizens whether Turks, Kurds, Arabs, Persians, Albanians, Lazes, Circassians, Chechens, Abkhaz and others were all equal members of the same Islamic umma'. Neither Muslim law, nor practice required the disclosure of ethnic identity. It was even against social ethics to probe into the ethnic identity of a citizen once he or she was recognized legally as an equal member of a religious community within the Ottoman state. According to the perceptions of that period, to attempt to divide them once more along racial or ethnic lines was impious and discriminatory. Moreover, the Ottoman melting pot, especially in Anatolia, intermingled a variety of peoples making clear distinctions between them impossible or difficult. The Kurds were "part and parcel of the unique culture that characterized Anatolia." 28 This is still the case. In a country like Turkey, it is next to impossible to state who is a "pure Turk". It

25 For instance: Nader Entassar, Kurdish Ethnonationalism, Boulder, Colorado, and London, Lynne Rienner Publishers, 1992.

${ }^{26}$ Amir Hassanpour, "Book Reviews: Kurdish Studies," Middle East Journal, 47/2 (Winter 1993), pp. 119-122.

${ }^{27}$ Graham E. Fuller, "Fate of the Kurds," Foreign Affairs, 72/1 (Spring 1993), p. 110.

${ }^{28}$ Ekrem Akurgal, "Kürtlerin Kökeni ve Türkiye'nin Kültür Bütünlüğü," Cumhuriyet, 8 June 1988. 
is impracticable, unnecessary and inoperative. For the same reason, to describe a "pure Kurd" is likewise a difficult task.

When the Turkish Republic adopted a legalistic definition of citizenship, the term "Turk" was devoid of racial, ethnic or religious content. The Lausanne Peace Treaty (1923) recognized the status of minority only to the three non-Muslim groups, i.e., the Armenians, the Greeks and the Jews. Centuries-old tradition and behaviour about the fraternity of all Muslims continued. Under the circumstances, the reference of the Turkish Constitution to the Turkish language as "the language of the state" implied a linguistic vehicle in education. Otherwise, the Kurds used their own language, privately and publicly, since the two communities came into contact centuries ago. The Turks have been hearing Kurdish spoken for about a thousand years. Spoken Kurdish was never banned, and legal restrictions on Kurdish in print have now been lifted.

The right of self-determination can be operative if a people is excluded from participation in the country's political process. In Turkey, there has not been such an exclusion on the basis of race, ethnicity, religion or colour. On the contrary, close to one-third of the members of the Turkish Grand National Assembly are of Kurdish origin belonging to different parties. While millions of Kurds live in the economically attractive western part of Turkey, quite a few Kurds occupy the highest posts in administration. Although some Westerners undermine such acceptance by arguing that the Kurds are admitted to all circles only if they behave as Turks, one may assert that it is only natural for professionals generally to respect the laws of the country. ${ }^{29}$

Unlike the situation in Yugoslavia or the Caucasus, the Turks and Kurds are not engaged in fighting against each other. During the 1995 elections in Turkey, a political party (HADEP) that styled itself as the "Kurdish Party", received only $1 / 7$ th of the votes cast by Turkey's citizens of Kurdish descent. When one remembers that the PKK had described these elections, during the campaign, as a "referandum" for its policies, the result showed only an alienation of the Kurdish mass, which overwhelmingly voted for the other parties. Turkey, other than Iran, has been one of the sanctuaries for the Kurds flecing from northern Iraq. The second Gulf War (1991) brought Turkey and the Iraqi Kurds closer. ${ }^{30}$

Thanks to the activities largely based on the lopsided campaign of the cultural organizations set up by the Kurds in Europe, the PKK has been able

${ }^{29}$ Nur Bilge Criss, "The Nature of PKK Terrorism in Turkey," Studies in Conflict and Terrorism, 18 (1995), p. 22.

${ }^{30}$ Michael M. Gunter, "A de facto Kurdish State in Northern Iraq," Third World Quarterly, 14/2 (1993), p. 22. 
to divert the attention of the Europeans away from its own illegal deeds and bloodshed to the situation of human rights in Turkey. PKK propaganda went to the extent of comparing Turkey with South Africa's apartheid policy, which is utterly unjust, unacademic and entirely ridiculous. ${ }^{31}$

PKK terrorism began when Armenian terrorist organizations stopped aiming at Turkish and related targets. Abdullah Öcalan (Apo), a flunk-out from the Faculty of Political Science of Ankara University, became the undisputed leader, purging and executing dissenters. He formed (1985) a PKK military wing, the Kurdish National Liberation Front (ERNK), and later a second one, the Kurdistan Popular Liberation Army (ARGK).

These armed detachments are formed by forcibly recruited young boys kidnapped or threatened when they reach the age of military service. The support of the families comes almost spontaneously because the children, originally boys and later young women as well, are virtual hostages in PKK hands. The frequent Turkish television interviews with those who manage to escape give ample proof of the methods of enlistment as well as the cruelty inflicted on them by the leadership.

Economic conditions, now further aggravated by the U.S. - led U.N. Security Council embargo on Iraq, cause a general unemployment as a result of which some of the young Kurds living in southeast Anatolia look to PKK recruitment as a possible solution to their problems. The U.N.'s binding decisions on Iraq, with which Turkey had a flourishing trade before 1991, costed the Turkish budget a loss of about 27 million U.S. dollars in terms of exports and investment opportunities. The embargo had a general stagnating influence on Turkish economy, especially in the southeast, and contributed to the growth of the PKK and the Islamic extremists.

It should be noted that reportedly the PKK received direct aid from foreign countries like Syria, Iran, Greece, Armenia, Cyprus, and Libya, in terms of money, arms and military training, logistical maintenance, and moral support. The PKK has in Damascus a major representative office and several branches in other Syrian cities. ${ }^{32}$ It maintains similar headquarters and camps in a number of Syrian-controlled Lebanese towns.

With such recruitment and foreign support, the PKK aims at the military, economic and social assets of Turkey, rival organizations, dissidents within its own ranks and non-cooperating Kurds. It attacks Turkish military and administrative targets, kills Turkish and Kurdish civilians, including

${ }^{31}$ See the inverview with a Kurdish militant (Faruk Serhat): EI Independiente, Madrid, 19 July 1990. For my reply: Türkkaya Ataöv, "La Situacion de los Kurdos en Turquia," El Independiente, 1 August 1990.

32"The PKK in Syria," Turkish Daily News, 19 January 1993. 
professionals like engineers, doctors and teachers who are there to assist the local people. It plants mines on roads, blows up bridges and railways, burns construction machinery, demolishes health centers, destroys schools, poisons water supplies, bombs hotels, kidnaps tourists, targets investment projects, and sets forests on fire. Illegal means such as drug trafficking, robbing jewellery stores and banks, and the extortion of money inside and outside Turkey constitute most of the financial resources of the PKK.

The PKK's guerilla tactics have been to conduct hit-and-run operations, killing even inactive or law-abiding Kurds, often including women and children. One of the PKK targets was Kurdish village guards, to whom the Turkish Government gave guns to protect themselves and also a monthly salary. It is reported that some of them sold their guns to the PKK guerillas, hoping that terrorism would not be totally overcome, and consequently their salaries would continue. ${ }^{33}$

The Turkish security forces, including army detachments, oppose the PKK guerillas by force of arms. There is mutual loss of life in northern Iraqi territory as well as on Turkish soil. But killings on account of power rivalries among the PKK leaders, the PKK's own extermination of whole families, losses due to blood feuds and personal vandettas, and the slaughters caused by the armed Hizbullah militants are all blamed on the Turkish security forces, and through them, the state itself.

The PKK is deeply involved in narcotics trade. ${ }^{34}$ It is using the drug profits to fund its campaign of terror. The International Criminal Police Organization, in addition to the German and Italian police, links the PKK to drug smuggling. Hence, it remains well-armed, including mortars and rockets. Battling the PKK now costs about 10 billion U.S. dollars per year.

While the PKK becomes increasingly active in Western Europe as well, it was banned in Germany and France. It opened a series of so-called "Kurdish information centers" in the United States, Britain, Germany, Greece, the Netherlands and Spain. These centers propagated, among other things, that the Turkish Armed Forces had destroyed thousands of villages and forcibly evacuated their Kurdish inhabitants. Although it is true that people were moved away from the border areas, and dwellings were crumbled to dust to prevent their use by the PKK, a total accusation of the Turkish administration fails to record that the rate of urbanization in the country and hence the influx of people from the rural areas to metropolitan centers are on of the highest in the world. The economic and security conditions as well as the continuing armed struggle, including the PKK's atrocities, urged many

${ }^{33}$ Criss, op. cit., p. 20.

${ }^{34}$ L'Express, 11-17 September 1992. 
Turkish citizens of Kurdish origin living in the southeast to migrate to the western parts of the country. The security forces destroyed some hamlets and villages, not only to deny to the PKK their strategic value, but also to protect the inhabitants of the isolated agglomerations. The PKK also fails to mention that their terrorists, wearing uniforms of security forces, have bumed down some of these villages in which Kurds used to live.

The Turkish Government is responding to PKK terrorism in a number of ways. In addition to employing troops in the area with occasional incursions into Northern Iraq, the Turkish Government also seems determined to reverse the economic circumstances of the area where the PKK operates. In spite of governmental incentives, private enterprise is generally reluctant to invest there. The state leads the investments. including the vast Southeastern Anatolian Project (GAP), which is an important facet of an overall development campaign in the area. It is a gigantic hydroelectric and irrigation complex destined to consist of 22 dams, 10 hydroelectric power plants and 37 irrigation systems with a daily expenditure of 1.7 million U.S. dollars. Although the population in the southeast is only 9 percent of the total, the investments there constitute 17.5 percent of the aggregate investments throughout the country. Investments very much exceed the tax collected in the region. ${ }^{35}$

The Turkish Government allocated in 19945.6 trillion Turkish Liras (approximately 186 million U.S. dollars) in economic aid and a development program covering agricultural and housing projects for ten provinces in the southeastern part of Anatolia. A year later, the government allocated another 2.8 trillion T.L. (about 47 million dollars) for infrastructure projects, and 288 billion T.L. (close to 4.8 million dollars) for food, medical aid and consumer goods.

\section{Conclusions:}

No matter what their motives are, the terrorists everywhere are undermining the democratic process. Their activities in India and in Turkey should be described as assaults on the democratic traditions of these two countries. Openness, pluralism, peaceful evolution and compromise are the tenets of democracy. One assumes that during the process groups learn to value forebearance, moderation, and consensus. Although there is much truth in this assumption, the democratic system may also irritate conflict, since each compromise may be used by groups for new demands through violence.

Further, assuming that the world was becoming more rationally modern, it was hoped that the problems caused by nationalism would be left

${ }^{35}$ The Republic of Turkey, Ministry of Foreign Affairs, Turkish Foreign Policy Issues: Human Rights in Turkey, Ankara, 1996, p. 19. 
behind, and that the world would commit itself to common interest and shared values. The relative absence of ethnic strife during the Cold War was treated as an evidence of the stability of the existing states. In the so-called New World Order, however, these assumptions proved to be incorrect, and ethnonationalism served as a motivation for a number of groups. Armed ethnic conflicts immediately occurred with the disintegration of the Soviet Union and Yugoslavia. In addition to significant Russian minorities in various former republics, and the conflicts within Georgia, Tajikistan, and Moldova as well as repeated Armenian attacks on Azerbaijan, there exist many more potential border disputes in the former Soviet Union. The fracturing of Iraq and Somalia indicates dangers for some other states. Great powers, which for centuries interfered in the events of Afghanistan, treated that country as a minor player in the game of international politics, but never in human terms.

On account of the upward trend visible in the instances mentioned above, even the democratic societies remain under a threat that is growing. They need to establish how best to conduct their counter-terrorism while maintaining democratic values. There is a strong trend in these socicties to respect the democratic rights of the citizens. They believe that failure to follow these principles causes a slide towards authoritarian rule.

The brutality of terrorist attacks, however, has caused some reservations about this rule of law approach. Some circles assert that terrorism is a form of covert warfare, and that it should be treated as such. Consequently, at least in some cases, the rules of the game may be changed, and democratic rights may be temporarily curtailed. Some governments declared virtual "war" on terrorism and cngaged in repression at human and political cost. But, on the other hand, this approach may well be counterproductive since it will generate additional support for terrorist groups, which will reappear as soon as repression comes to an end. Moreover, "declaring war" on terrorists may give them some "legitimacy", taking them out of the classification of common criminals. Further, a number of liberal societies stress the need to deal with terrorism only within the confines set by respect for democratic values.

As a third alternative, some circles now argue that the laws may be legitimately altered to meet the new terrorist threats. Some advocate regional, for instance European, police force. Others suggest an international court to try terrorists. Almost all concerned underline that possible terrorist access to weapons of mass destruction must be prevented. There is, indeed, a long tradition of states combining their efforts in the battle against types of crime which affect many countries. There is also sufficient basis in international law for cooperation among states to combat terrorism. For instance, the U.N. General Assembly resolutions of 1994 (49/185/ and of 1995 (50/186) 
reiterate great concern over gross violations of human rights perpetrated by terrorist groups. They call upon states to take all necessary and effective measures to prevent acts of terrorism whereever and by whomever committed.

In order to raise the effectiveness of the agreements already made, all states must strictly fulfill their obligations, and must not apply different yardsticks to the various acts of international terrorism. All states must take appropriate measures at the national level, harmonize their domestic legislation with international conventions, perform their international obligations, and prevent the preparation in their territory acts directed against other states.

Believing in the values that lie at the very base of modern India and modern Turkey, we have no other alternative but to uphold secular democracy in our countries. Our determination should be all the more unswerving when terrorism challenges it. To dislodge India and Turkey from their secular and democratic foundations will have repercussions beyond their borders.

In spite of violence, India succeeded so far in protecting its democratic system. The country's federal structure continues to offer a framework within which national and state parties share power. The federal structure incorporates the impact of ethno-based violence. It is difficult to unite the Hindu majority or the Hindi-spcaking regions, just as it is an unmanagable task to unite the non-Hindus against the center. Politicians should not instigate the feelings of hatred of their followers by reminding them, for electoral or other purposes, certain previous conflicts. Instead of retreating to the golden age of Rama, no matter how glorious it may be, and demanding from others to purge the country from the so-called "foreign impurities", a constructive way of rediscovery is to emphasize India's rich artistic, cultural, religious and philosophical traditions that include Islamic contributions as well.

Some circles in Turkey and abroad suggest an ill-defined "political solution" in connection with the Kurdish question. The Turkish governments and citizens in general favour the survival of the country as a nation-state. The question is how to manage the PKK terrorism, and also satisfy some foreign quarters which use the issue against Turkey's integration with the West. Irrespective of the PKK propaganda and exaggerations, the existing limitations on frcedoms and the occasional human rights violations affecting not only Kurds but everyone in southeastern Anatolia may be brought to an end.

Since there are many different situations where ethnic groups are concerned, each case has to be assessed in the light of its particular circumstances. However, some general observations may be made. First, the protection of persons belonging to such groups has to be seen essentially in 
the interest of the state and of the majority. If the state exhibits care and loyalty to all citizens, it can expect loyalty in return by those who will have an interest in the stability and in the well-being of the state. This consideration should apply to minorities all over the world, certainly including the Turkish minorities in a number of neighbouring countries.

Secondly, solutions should be sought within the framework of the state. It is possible to achieve the self-realization as an ethnic group within the frontiers of the existing state. Secession is not necessarily an answer to the problems and the aspirations of the minorities. In most cases, secession is neither necessary, nor helpful. In view of the fact that the minorities are generally dispersed over large areas, living with persons who are members of other groups, changing borders are neither feasible, nor desirable. Secession may also lead to unstable states with new minorities. Moreover, it is almost impossible to find a government willing to cede even a small section of its territory. Examples prove beyond doubt that even the very mentioning of such an alternative causes a greater rigidity in the attitude of the central authorities.

The question of so-called "state-sponsored terrorism" has always been a major preoccupation of human rights organizations, particularly in the West, and needs to be addressed. It is too simplistic to reason that any action taken by state authority in combatting terrorist groups falls under this category. Whenever such action has become unavoidable, and indeed necessary, whether in India or in Turkey or may be elsewhere, it may be assumed that it has been taken when all democratic avenues have failed. What is more, it is has been taken against unbridled terrorist outfits who by the sheer terror they practice cowed down the silent majority with the aim of disrupting law and order and destabilizing established institutions and national structures and who can in no sense be said to be representative of the people in whose name they purport to fight. Under these conditions, to speak more of the rights of such groups while belittling or even ignoring the overwhelming interest of the broad majority of the people may be termed as travesty of justice. In the final analysis, when faced with such a choice, no doubt extremely difficult and without any guarantee of success, governmental authorities are inclined to revert to the old maxim of assuring the greatest good of the greatest numbers. This should not be described as "the tyranny of the majority" as long as the small minority employs terrorist methods.

Under the present circumstances, the "golden rule" seems to be a recognition of the fact that the questions relating to minorities may be resolved in democratic framework, and also that self-determination and secession are not the one and the same thing. 